\title{
Medusaegraptus (Chlorophyta, Dasycladales) from the Pridolian to middle Lochkovian Indian Point Formation, New Brunswick, Canada
}

\author{
Steven T. LoDuca ${ }^{1 \star}$, Randall F. MilleR ${ }^{2}$, And Reginald A. Wilson ${ }^{3}$ \\ 1. Department of Geography and Geology, Eastern Michigan University, Ypsilanti, Michigan 48197, USA \\ 2. Steinhammer Palaeontology Laboratory, Natural Science Department, New Brunswick Museum, Saint John, \\ New Brunswick E2K 1E5, Canada \\ 3. Geological Surveys Branch, Department of Energy and Mines, PO Box 50, Bathurst, \\ New Brunswick E2A 3Z1, Canada \\ ${ }^{*}$ Corresponding author <sloduca@emich.edu>
}

Date received: 26 February 2013 g Date accepted 25 March 2013

\begin{abstract}
Carbonaceous compressions from the Pridolian to middle Lochkovian Indian Point Formation in the Flatlands area of New Brunswick comprising a central axis with irregularly arranged unbranched appendages are assigned to Medusaegraptus mirabilis. This is the first report of intact thalli of this noncalcified macroalgal taxon from a locality outside of western New York. The biotic composition, stratigraphic context, and sedimentology of this occurrence suggest a shallow-marine depositional setting roughly comparable to that for the type material of Medusaegraptus mirabilis from Gasport, New York.
\end{abstract}

\section{RÉSUMÉ}

Les fossiles carbonés comprimés de la formation d'Indian Point, située dans la région de Flatlands du Nouveau-Brunswick et qui date du Pridolien au Lochkovien moyen, sont attribués à Medusaegraptus mirabilis; ils présentent un axe central avec des appendices non ramifiés et disposés de façon irrégulière. C'est la première fois qu'on signale la présence de thalles intacts de ce taxon de macroalgues non calcifiées dans une localité ailleurs que dans l'ouest de l'État de New York. La composition biotique, le contexte stratigraphique et les données sédimentologiques permettent de penser à un dépôt marin peu profond à peu près comparable à ce qu'on trouve dans le cas de Medusaegraptus mirabilis de Gasport, dans l'État de New York.

[Traduit par la redaction] 


\section{INTRODUCTION}

In 1925, Rudolf Ruedemann erected Medusaegraptus on the basis of material from the Silurian of western New York. Two species were assigned to the genus: the type, Medusaegraptus mirabilis from the Lockport Group near Gasport; and Medusaegraptus graminiformis from the younger (Pridolian) Bertie Group in the Buffalo area. The latter had been described originally by Pohlman (1886) under the name Chondrites graminiformis as a "marine plant". Ruedemann (1925) classified Medusaegraptus as a dendroid graptolite, but Bulman $(1938,1955)$ and Mierzejewski (1986) expressed doubt concerning Ruedemann's assignment and suggested an algal affinity. Uncertainty over affinity arises from a problem common to many early Paleozoic marine taxa with a branched form preserved as thin films of carbon: the gross morphology allows for either an animal or an algal affinity. LoDuca (1990) formally transferred Medusaegraptus to the green algal order Dasycladales on the grounds that its general form, comprising an unbranched cylindrical axis surrounded in irregular fashion by numerous unbranched cylindrical appendages, is characteristic of early Paleozoic dasycladaleans. In addition, none of the material assigned to the genus shows key graptolite features, such as triad budding or fusellar structure, and the type material of the genus occurs in direct association with undoubted algae (LoDuca, 1990). Results of a later geochemical study of Medusaegraptus mirabilis supported reassignment to the algae (LoDuca and Pratt 2002).

Apart from the New York material described by Ruedemann (1925), Silurian occurrences of Medusaegraptus have been reported from the Czech Republic (Bouček 1957), Michigan (Ehlers and Kesling 1957), Gotland (Hede 1960), Australia (Rickards et al. 1995), and additional localities in New York (LoDuca 1990; LoDuca and Brett 1997; Ciurca 2002). In addition, the genus has been reported from the Ordovician of China (Mu et al. 1979; Lin 1984), and Shrock (1928) and Tinn et al. (2009) reported what were regarded as possible occurrences from the Silurian of Indiana and Estonia, respectively. Here, a new occurrence of Medusaegraptus is reported from the Pridolian to middle Lochkovian Indian Point Formation in the Flatlands area of New Brunswick (Fig. 1).

\section{GEOLOGIC SETTING}

The rocks underlying the Restigouche area, which encompasses the Flatlands fossil locality (Fig. 1), constitute part of a post-Taconian successor basin known as the Matapedia Cover Sequence (Fyffe and Fricker 1987), also referred to as the Gaspé Belt (Bourque et al. 1995). Upper Ordovician to Middle Devonian rocks of the Matapedia Cover Sequence overstep the margins of two major zones of deformed Cambrian to Middle Ordovician rocks, namely the Humber Zone (Laurentian margin) to the northwest and Ganderia (peri-Gondwanan tracts) to the southeast (van Staal et al. 2009). The stratigraphic framework and evolution of the Matapedia Cover Sequence in northern New Brunswick has been described by Wilson et al. (2004) and Wilson and Kamo (2008, 2012). Following the Silurian collision between Ganderia and Laurentia (Salinic Orogeny), Matapedia Cover Sequence sedimentation occurred in a retroarc foreland setting with respect to northwestward (present coordinates) migration of the Avalonian (Acadian) orogenic wedge (Wilson et al. 2004). In the Restigouche area, uplift associated with the Salinic Orogeny produced a widespread middle Silurian erosional unconformity that separates Upper Silurian rocks of the Chaleurs Group from underlying Lower Silurian rocks of the Quinn Point and Matapedia groups (Wilson et al. 2004; Wilson and Kamo 2012). The Chaleurs Group in the Restigouche area consists of reefal carbonates of the West Point Formation (limestone bioherms and associated peri-reefal facies), and overlying and interfingering calcareous sedimentary rocks of the Indian Point Formation (Wilson et al. 2004; Fig. 1).

\section{Indian Point Formation: lithology and depositional setting}

The Indian Point Formation is a lithologically diverse unit consisting mainly of moderately to strongly calcareous mudstone, fine-grained sandstone, and wackestone, all of which commonly contain comminuted fossil debris. Minor lithotypes include coarse-grained sandstone, wackestonepackstone biostromes, limestone conglomerate, and polymictic conglomerate (Wilson et al. 2004). Fossils include stromatoporoids, brachiopods, trilobites, and crinoids; some sections contain abundant rugose corals. In the Flatlands area, including the study site, the dominant lithological association comprises greenish-grey, mediumto thick-bedded (up to roughly $1 \mathrm{~m}$ ), locally fossiliferous, moderately to strongly calcareous mudstone with local thin beds of calcareous siltstone and fine-grained, parallellaminated sandstone (Fig. 2). The fossils described herein were recovered in October 2011 from tumbled-out blocks of calcareous mudstone along a cut through the Indian Point Formation on the south side of Highway 134, opposite Island View Road, approximately $1 \mathrm{~km}$ east of Flatlands (Fig. 3). Additional fossils in the same blocks include scarce brachiopods, trilobites, and crinoid fragments. No trace fossils are present within the blocks.

Spores and acritarchs in the Indian Point Formation indicate a Pridolian to middle Lockhovian age (Wilson et al. 2004), as do brachiopod taxa described from the unit across the river from the study area, in Gaspé, Quebec (Bourque and Lachambre 1980). The Indian Point Formation is 


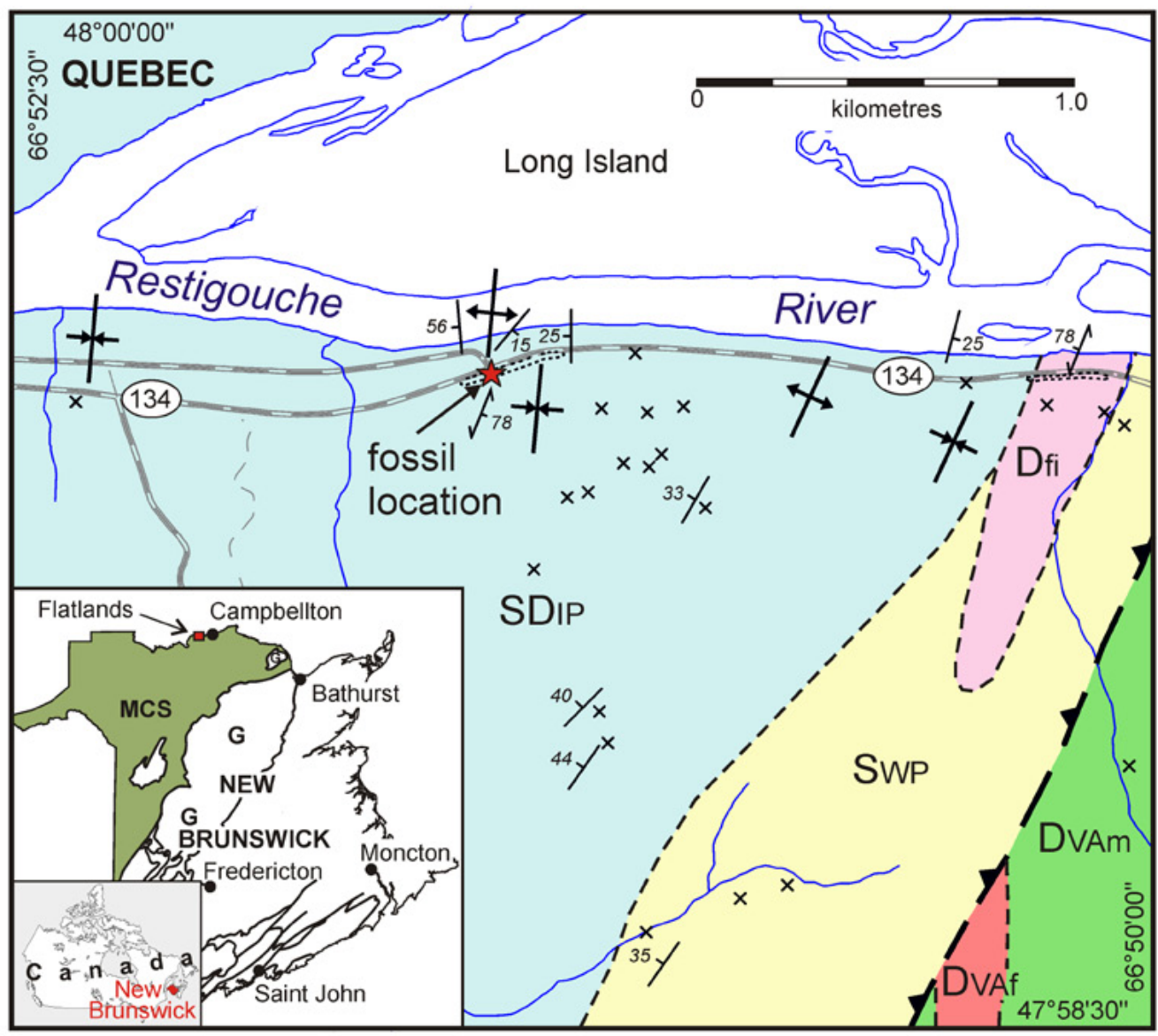

\section{EARLY DEVONIAN}

$D_{f i}$ porphyritic felsic intrusive rocks

Dalhousie Group (Val d'Amour Formation)

DVAf felsic volcanic rocks

DVAm mafic volcanic rocks

\section{LATE SILURIAN to EARLY DEVONIAN} Chaleurs Group (Indian Point Formation) SDIP calcareous sedimentary rocks

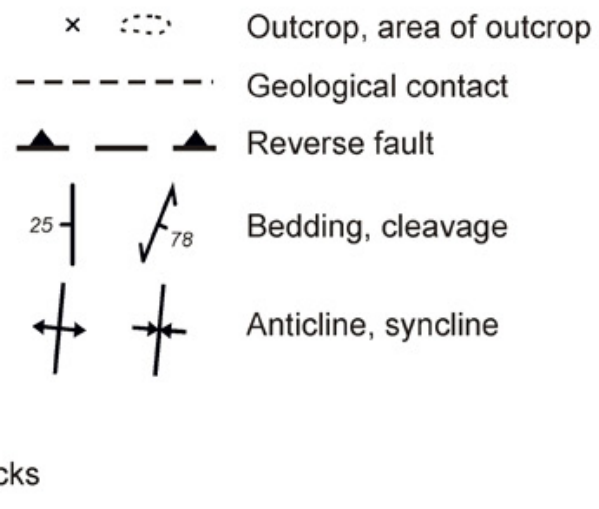

Chaleurs Group (West Point Formation)

SWP limestone and peri-reefal sedimentary rocks

Figure 1. Geological map of Flatlands, New Brunswick. Folded beds of the Indian Point Formation are exposed along Highway 134. Inset shows location of Flatlands area within New Brunswick. MCS - middle Paleozoic rocks of the Matapedia Cover Sequence; G - lower Paleozoic rocks of Ganderia terrane.

intruded by the Squaw Cap Felsite, which has yielded a middle Lochkovian U-Pb (zircon) age of $415.0 \pm 0.5 \mathrm{Ma}$ (Wilson et al. 2004), and provides an upper age limit for the unit.

The lithology, sedimentology, and paleontology of the Indian Point Formation indicate deposition in a near-shore marine-shelf environment (Wilson et al. 2004). Fully marine conditions are indicated by the presence of brachiopods, crinoids, corals, stromatoporoids, and trilobites, but palynological evidence indicates some input from terrestrial sources (Wilson et al. 2004), thereby pointing to a nearshore setting. The rarity of cross-laminated or ripplelaminated beds suggests deposition below fair-weather wave base. Nonetheless, water depth need not have exceeded a 


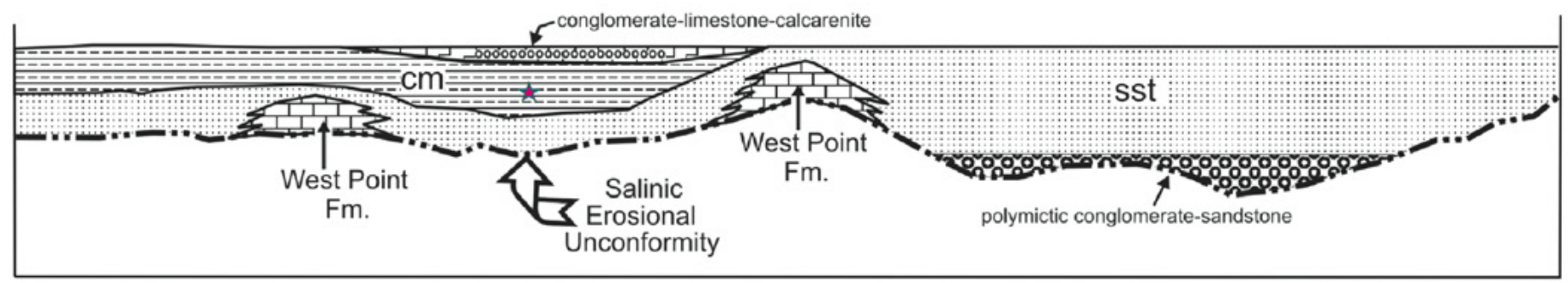

Figure 2. Sedimentary facies of the Indian Point Formation modified after Wilson et al. (2004). Abbreviations: sst $=$ thinbedded calcareous siltstone-sandstone facies; $\mathrm{cm}=$ medium- to thick-bedded calcareous mudstone facies. The red star shows the presumed stratigraphic position of Medusaegraptus mirabilis at the Flatlands fossil locality.

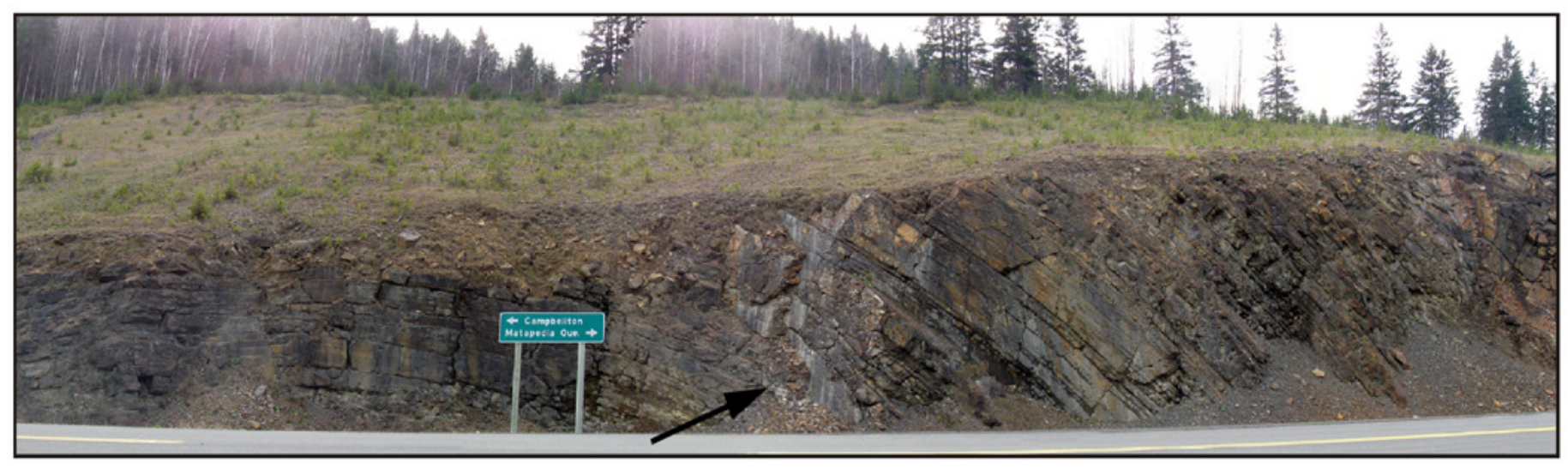

Figure 3. Outcrop of the Indian Point Formation on Highway 134. Arrow indicates collection location of Medusaegraptus mirabilis in tumble-out blocks from the outcrop.

few metres because sea-floor topography related to reefs in the West Point Formation may have acted to baffle wave and current energy. Lack of trace fossils and preservation of organic material suggest low oxygen conditions near the sea floor. A complete lack of graded beds, sole markings, and convolute lamination argue against deposition as turbidite beds. Marine sedimentation was relatively short-lived, as a Lochkovian-Emsian regression began with local deposition of conglomerate and limestone (wackestone and packstone) at the top of the formation, and continued with subaerial volcanism of the conformably overlying Val d'Amour Formation (Dalhousie Group; Wilson et al. 2005).

\section{SYSTEMATIC PALEONTOLOGY}

Order Dasycladales Pascher, 1931

Family Seletonellaceae Korde, 1971; emend. Bassoullet et al., 1975

Genus Medusaegraptus Ruedemann, 1925; emend. LoDuca, 1990
Remarks: Twelve species have been assigned to Medusaegraptus, two with uncertainty. Seven of these, including one of the species assigned to the genus with uncertainty, are known only from the Ordovician of China (Mu et al. 1979; Lin 1984). In a review of species assigned to the genus from North America and Europe by LoDuca (1990), two were considered not to be medusaegraptids. Of the remaining three species, all of which are Silurian, Medusaegraptus mirabilis and Medusaegraptus graminiformis are known exclusively from North America, whereas Medusaegraptus similis is known only from the Czech Republic.

Medusaegraptus mirabilis Ruedemann, 1925; emend. LoDuca, 1990 (Figs. 4A, C- H)

Medusaegraptus mirabilis Ruedemann 1925, p. 30, pl. 9, fig. 1-6, pl. 10, fig. 1-4, pl. 11, fig. 1. Medusaegraptus (?) mirabilis Ruedemann: Shrock 1928, p. 33.

Medusaegraptus mirabilis Ruedemann: Ruedemann 1947, p. 242 , pl. 41 , fig. $13-15$, pl. 42 , fig. 1-2. 

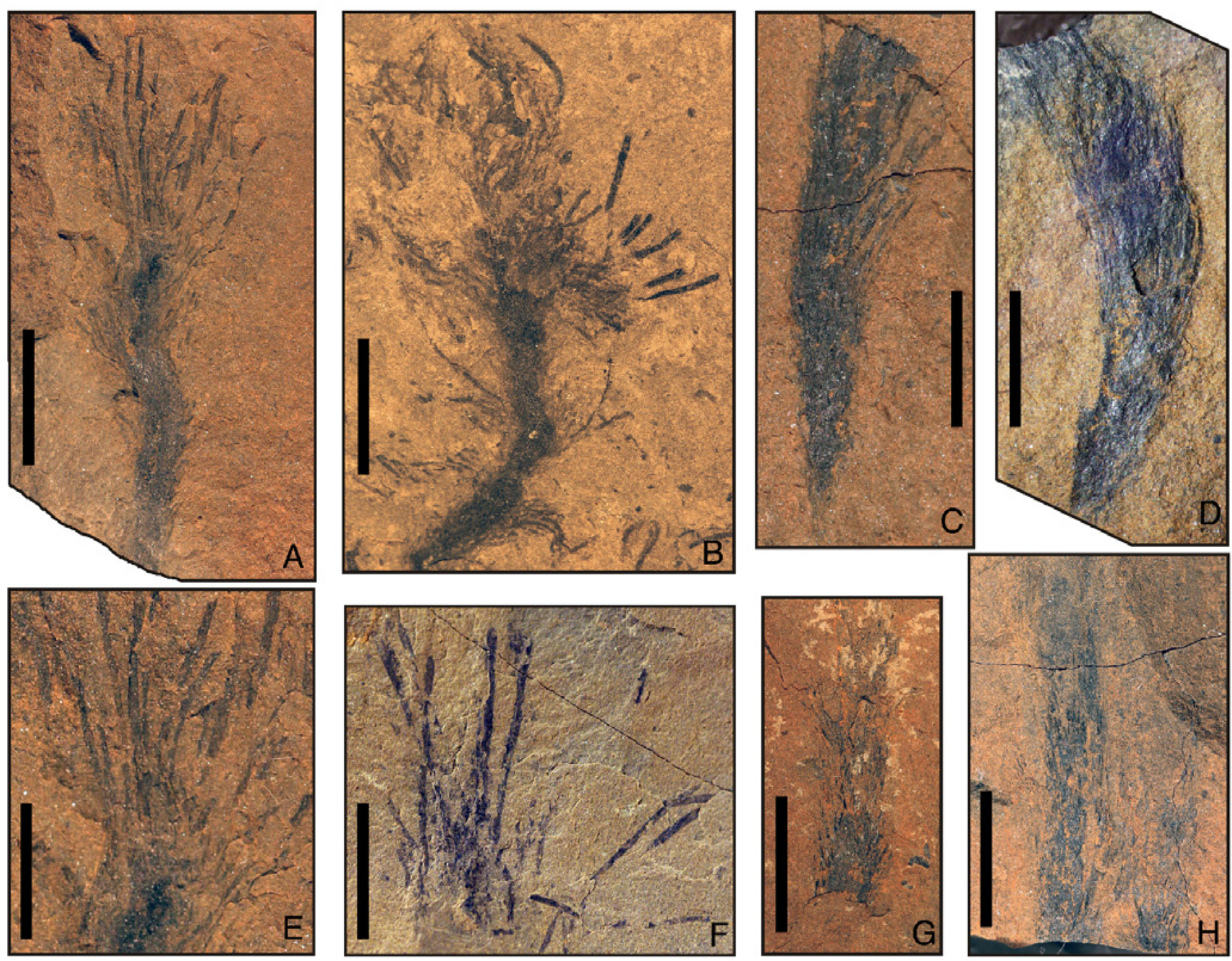

Figure 4. (A) Medusaegraptus mirabilis, upper part of thallus with distinct capitulum, Indian Point Formation, Flatlands, New Brunswick (NBMG 11062/1). (B) Medusaegraptus mirabilis, a small specimen with a distinct capitulum from the type locality near Gasport, New York (UMMP 74003). (C, D) Medusaegraptus mirabilis, Indian Point Formation, Flatlands (NBMG 16279 and NBMG 16280, respectively). (E) Enlargement of upper part of specimen shown in A. (F) Upper part of thallus of Medusaegraptus mirabilis, Indian Point Formation, Flatlands (NBMG 16275). (G, H) Medusaegraptus mirabilis main axes largely stripped of laterals, Indian Point Formation, Flatlands (NBMG 16276 and NBMG 16277, respectively). Scale bars for A, B, F-H, $1 \mathrm{~cm}$; for C-E, $0.5 \mathrm{~cm}$.

Medusaegraptus mirabilis Ruedemann: LoDuca 1990, p. 473, figs. 3.1-3.7.

Medusaegraptus mirabilis Ruedemann: LoDuca and Brett 1997, fig. 14.13b, c, d.

Material: NBMG 11062, NBMG 16275, NBMG 16276, NBMG 16277, NBMG 16279, NBMG 16280. The specimens are reposited in the Palaeontology Collection of the New Brunswick Museum (NBMG).

OCCURRENCE: All specimens are from tumbled-out blocks of the Pridolian to middle Lockhovian Indian Point
Formation exposed along the south side of Highway 134 opposite Island View Road, Flatlands, New Brunswick (NTS Map 21 O/15; 4759.49’ N; 6651.47’W) (Fig. 1).

DesCRIPTION: Specimens are preserved as black carbonaceous compressions with little or no relief. The thallus for specimen $11062 / 1$ is $38 \mathrm{~mm}$ long and $14 \mathrm{~mm}$ wide at its widest point and comprises an undivided main axis surrounded by thin, unbranched laterals (Fig. 4A, E). The basal part of the thallus is missing. The main axis is $22.5 \mathrm{~mm}$ long and $1.7 \mathrm{~mm}$ wide; it is largely concealed by 
overlying laterals. Laterals along the upper part of the main axis form a distinct capitulum. The capitulum-forming laterals are $14 \mathrm{~mm}$ long; each maintains a nearly uniform width, expanding very slightly distally to a maximum width of $0.3 \mathrm{~mm}$. Laterals along the lower part of the main axis are shorter and thinner, on average being $7 \mathrm{~mm}$ long and $0.15 \mathrm{~mm}$ wide. All laterals have abrupt, bluntly rounded terminations. Laterals are arranged around the main axis in an irregular (aspondyl) fashion. Reproductive structures are not evident. Specimen 16275 appears to represent only the uppermost part of a thallus and consists of a cluster of elongate laterals up to $20 \mathrm{~mm}$ in length (Fig. 4F). Lateral width increases slightly distally; most are $0.55 \mathrm{~mm}$ wide near the base, increasing gradually to $0.7 \mathrm{~mm}$ at the distal tips. Specimens 16279 and 16280 are about half the size of $11062 / 1$ but are otherwise similar in terms of thallus architecture (Fig. 4C, D). Specimens on slabs 16276 and 16277 consist of main axes, each nearly $3 \mathrm{~mm}$ wide, largely stripped of laterals (Fig. 4G, H). Because the matrix is highly friable, none of the specimens was examined using scanning electron microscopy.

REMARKS: In having unbranched lateral appendages of near-constant width arranged irregularly around an undivided central axis, the New Brunswick material accords in all respects with the emended diagnosis of Medusaegraptus by LoDuca (1990). Measurements for species currently assigned to the genus most similar to the New Brunswick material are provided in Table 1. Among these, only one, Medusaegraptus mirabilis, has dimensions for lateral width that overlap with the New Brunswick material. All of the other species are characterized by thinner laterals. In addition, the largest of the nearly complete New Brunswick specimens (11062/1) accords with the type material of Medusaegraptus mirabilis in terms of main axis width and lateral length, lateral density along the main axis, and development of a distinct capitulum (Fig. 4A, B). For 16279 and 16280, it is possible that these specimens represent a species of Medusaegraptus apart from Medusaegraptus mirabilis owing to their relatively small dimensions. Such a determination, however, would require additional material and so these small specimens are herein regarded as early growth stages of Medusaegraptus mirabilis. Specimens on slabs 16276 and 16277 are regarded as main axes of Medusaegraptus mirabilis largely stripped of laterals, a condition known for thalli of this species from the type area (LoDuca, 1990). The width of these specimens is consistent with main axis width for Medusaegraptus mirabilis, but exceeds that for all other species assigned to the genus.

A key aspect of the anatomy of dasycladalean algae is the siphonous nature of their thalli (Berger and Kaever, 1992). Ruedemann (1925) described the appendages of Medusaegraptus mirabilis as hollow. Such a structure could not be confirmed in a reexamination of the type material by LoDuca (1990), but additional material collected by one of us (STL) from the type locality after publication of that study suggests that the laterals are in fact thin-walled, hollow tubes without internal cross walls and that the main axis has a similar construction. Siphonous structure is not evident in the New Brunswick material assigned to this taxon but, like most specimens of Medusaegraptus mirabilis from the type locality, this is regarded to be a consequence of compression.

\section{DISCUSSION}

New Brunswick specimens assigned herein to Medusaegraptus mirabilis are among the youngest known for the genus. The only other reports of Medusaegraptus from post-Ludlovian strata are specimens of Medusaegraptus graminiformis from the Pridolian of New York and Michigan (Ruedemann 1925; Ehlers and Kesling 1957), and specimens referred to the genus without species affiliation by Ciurca (2002), also from the Pridolian of New York. Apart from possible fragments reported from the Silurian Mississinewa Shale of Indiana (Shrock 1928), this is the first report of Medusaegraptus mirabilis from a locality outside of western New York.

Important parallels exist between the New Brunswick occurrence of Medusaegraptus mirabilis and that for the type material near Gasport, New York, described in detail by LoDuca and Brett (1997). In both cases, specimens are preserved within fine-grained strata of mixed siliciclastic-

Table 1. Thallus measurements (in mm) for various Medusaegraptus species and the new specimens from New Brunswick.

\begin{tabular}{lccccccc}
\hline & M. mirabilis & M. graminiformis & M. similis & M. hispidis & NBMG 11062/1 & NBMG 16275 & NBMG 16279 \\
\hline main axis width & 1.5 to 4.0 & 0.6 to 1.2 & 1.50 & 0.5 to 2.0 & 1.7 & $\mathrm{x}$ & $?$ \\
main axis length & 35 to 150 & up to 40 & 20.0 & 8 to 15 & 22.5 & $\mathrm{x}$ & 17.5 \\
lateral width & 0.2 to 1.5 & 0.10 & 0.10 & 0.1 to 0.125 & 0.15 to 0.30 & 0.70 & 0.20 \\
lateral length & 5 to 30 & 3 to 10 & 7.0 & 3 to 5 & 7 to 14 & 20.0 & 6 \\
lateral density & high & low & low & high & high & $\mathrm{x}$ & high \\
\hline
\end{tabular}


carbonate composition, and the respective units were deposited across a sea floor with an undulating topography controlled by underlying reefs. In addition, bioturbation is minimal and the associated shelly biotas are sparse and comprise normal marine taxa. These similarities suggest roughly comparable depositional environments. A key difference between the two occurrences is that dendroid graptolites are abundant at the type locality, whereas they have not been reported from the Indian Point Formation. The reason for this discrepancy is not clear, but the lack of such taxa in the Indian Point Formation is nevertheless in keeping with an algal affinity for the material described herein, and for Medusaegraptus mirabilis more generally. At the type locality, a variety of noncalcified macroalgal taxa occur in association with Medusaegraptus mirabilis, including Chaetocladus ruedemanni and "Chondrites" versus (LoDuca 1997; LoDuca and Brett 1997). The only identifiable algal material from the Indian Point Formation recovered to date is the present material. It is possible, however, that additional algal taxa are represented among the fragments of carbonized material referred to broadly as "plant matter" by Wilson et al. (2004). At the type locality, most specimens of Medusaegraptus mirabilis are complete and some are preserved upright, in growth position, indicating little and in some cases no transport prior to burial (LoDuca 1990, LoDuca and Brett 1997). The New Brunswick material, is more fragmentary in nature, pointing to the possibility of some post-mortem transport.

\section{ACKNOWLEDGMENTS}

We thank reviewers Brian Pratt and Lucy Muir, and editor Rob Fensome for helpful comments to improve the manuscript. Work by STL was funded in part by National Science Foundation grant EAR 1250756.

\section{REFERENCES}

Bassoullet, J.-P., Bernier, P., Deloffre, R., Genot, P., Jaffrezo, M., Poignant, A.F., and Segonzac, G. 1975. Réflexions sur la systématique des Dasycladales fossils: étude critique de la terminologie et importance relative des critères de classification. Géobios, 8, pp. 259-290.

Berger, S. and Kaever, M. 1992. Dasycladales: an illustrated monograph of a fascinating algal order. Georg Thieme, Stuttgart, $247 \mathrm{p}$.

Bouček, B. 1957. The dendroid graptolites of the Silurian of Bohemia. Ústředního ústavu geologického, 23, pp. 1-294.

Bourque, P.-A. and Lachambre, G. 1980. Stratigraphie du Silurien et du Dévonien basal du sud de la Gaspésie, Québec. Direction générale de la recherche géologique et minérale, Ministère de l'énergie et des ressources,
Québec, ES-30, 123 p.

Bourque, P.-A., Brisebois, D., and Malo, M. 1995. Gaspé Belt. In Chapter 4 of Geology of the Appalachian-Caledonian Orogen in Canada and Greenland. Edited by H. Williams. Geological Survey of Canada, Geology of Canada, no. 6, pp. 316-351.

Bulman, O.M.B. 1938. Graptolithina. In Handbuch der Paläozoologie. Edited by O. H. Schindewolf. Gebrüder Bornträger, Berlin, pp.1-91.

Bulman, O.M.B. 1955. Graptolithina. In Treatise on invertebrate paleontology, part V. Edited by R. Moore. Geological Society of America and University of Kansas Press, Lawrence, pp. V3-V99.

Ciurca, S.J. 2002. Discovery of eurypterids and Medusaegraptus sp. in the Late Silurian Syracuse Formation (Salina Group) along Oatka Creek at Garbutt, New York. Proceedings of the Rochester Academy of Science, 19, pp. 122-123.

Ehlers, G.M. and Kesling, R.V. 1957. Silurian rocks of the Northern Peninsula of Michigan; Michigan Geological Society, guidebook for annual geological excursion, $63 \mathrm{p}$.

Fyffe, L.R. and Fricker, A. 1987. Tectonostratigraphic terrane analysis of New Brunswick. Maritime Sediments and Atlantic Geology, 23, pp. 113-123.

Hede, J.E. 1960. The Silurian of Gotland. In The lower Palaeozoic of Scania. The Silurian of Gotland Excursion Guide. Edited by G. Regnell and J.E. Hede. 21st International Geological Congress, Copenhagen, 1960, pp. $44-89$.

Korde, K.B. 1971. K sistematike i evoljucii vodoroslej iz porjadka Dasycladales (Chlorophyta). Byulleten' Moskovskogo Obshchestva Ispytatelei Prirody Otdel Geologicheskii, 46, pp. 134-135.

Lin, Y. 1984. Some new material of Ordovician medusaegraptids. Acta Palaeontologica Sinica, 23, pp. 478-480.

LoDuca, S.T. 1990. Medusaegraptus mirabilis as a noncalcified dasyclad alga. Journal of Paleontology, 64, pp. 469-474.

LoDuca, S.T. 1997. The green alga Chaetocladus (Dasycladales). Journal of Paleontology, 71, pp. 940-949.

LoDuca, S.T. and Brett, C.E. 1997. The Medusaegraptus epibole and Ludlovian Konservat-Lagerstätten of eastern North America. In Paleontological events: stratigraphic, ecological, and evolutionary implications. Edited by C. E. Brett and G. Baird. Columbia University Press, New York, pp. 369-405.

LoDuca, S.T. and Pratt, L. 2002. Stable carbon-isotopic compositions of compression fossils from Lower Paleozoic Konservat-Lagerstätten. Palaios, 17, pp. 287-291. http:// dx.doi.org/10.1669/0883-1351(2002)017<0287:SCICOC $>2.0 . \mathrm{CO} ; 2$

Mierzejewski, P. 1986. Ultrastructure, taxonomy, and affinities of some Ordovician and Silurian organic 
microfossils. Palaeontologia Polonica, 47, pp. 129-220.

Mu, E., Ge, M., Chen, X., Ni, Y., and Lin, Y. 1979. Lower Ordovician graptolites of southwest China. Palaeontologia Sinica, 156, pp. 159-170.

Pascher, A. 1931. Systematische Übersicht über die mit Flagellaten in Zusammenhang stehenden Algenreihen und Versuch einer Einreihung dieser Algenstamme in die Stämme des Pflanzenreiches. Botanisches Centralblatt, Beiheft, 48, pp. 317-332.

Pohlman, J. 1886. Fossils from the Waterlime Group near Buffalo. Bulletin of the Buffalo Society of Natural History, 5, pp. 23-33.

Rickards, R.B., Packham, G.H., Wright, A.J., and Williamson, P.L. 1995. Wenlock and Ludlow graptolite faunas and biostratigraphy of the Quarry Creek district, New South Wales, Memoir - Association of Australasian Palaeontologists, 17, pp. 1-69.

Ruedemann, R. 1925. Some Silurian (Ontarian) faunas of New York. New York State Museum Bulletin, 265, 84 p.

Ruedemann, R. 1947. Graptolites of North America. Geological Society of America Memoir 19, 652 p.

Shrock, R. 1928. A new graptolite fauna from the Niagaran of northern Indiana. American Journal of Science, 16, pp. 1-38. http://dx.doi.org/10.2475/ajs.s5-16.91.1

Tinn, O., Meidlaa, T., Ainsaara, L., and Pani, T. 2009. Thallophytic algal flora from a new Silurian Lagerstätte. Estonian Journal of Earth Sciences, 58, pp. 38-42. http:// dx.doi.org/10.3176/earth.2009.1.04

van Staal, C.R., Whalen, J.B., Valverde-Vaquero, P., Zagorevski, A., and Rogers, N. 2009. Pre-Carboniferous, episodic accretion-related, orogenesis along the Laurentian margin of the northern Appalachians. In Ancient orogens and modern analogues. Edited by J.B.
Murphy, J.D. Keppie and A.J. Hynes. Geological Society of London Special Publication, 327, pp. 271-316.

Wilson, R.A. and Kamo, S. 2008. New U-Pb ages from the Chaleurs and Dalhousie groups: implications for regional correlations and tectonic evolution of northern New Brunswick. In Geological Investigations in New Brunswick for 2007. Edited by G.L. Martin. New Brunswick Department of Natural Resources; Minerals, Policy and Planning Division, Mineral Resource Report 2008-1, pp. 55-77.

Wilson, R.A. and Kamo, S.L. 2012. The Salinic Orogeny in northern New Brunswick: geochronological constraints and implications for Silurian stratigraphic nomenclature. Canadian Journal of Earth Sciences, 49, pp. 222-238. http://dx.doi.org/10.1139/e11-041

Wilson, R.A., Burden, E.T., Bertrand, R., Asselin, E., and McCracken, A.D. 2004. Stratigraphy and tectonosedimentary evolution of the Late Ordovician to Middle Devonian Gaspé Belt in northern New Brunswick: evidence from the Restigouche area. Canadian Journal of Earth Sciences, 41, pp. 527-551. http://dx.doi. org/10.1139/e04-011

Wilson, R.A., Kamo, S., and Burden, E.T. 2005. Geology of the Val d'Amour Formation: revisiting the type area of the Dalhousie Group, northern New Brunswick. In Geological investigations in New Brunswick for 2004. Edited by G.L. Martin. New Brunswick Department of Natural Resources; Minerals, Policy and Planning Division, Mineral Resource Report 2005-1, pp. 167-212.

Editorial responsibility Robert A. Fensome 